\title{
Complete control of Penicillium expansum on apple fruit using a combination of antagonistic yeast Candida oleophila
}

\author{
Víctor Guerrero $^{1 *}$, Cesar Guigon ${ }^{2}$, David Berlanga ${ }^{3}$, and Damaris Ojeda ${ }^{1}$
}

Three Candida oleophila strains (L06, L07 smooth, and L07 rough) were evaluated in vivo and in vitro as biocontrol agents against Penicillium expansum on postharvest 'Golden Delicious' apples (Malus domestica Borkh.) in Chihuahua, Mexico. The in vivo and in vitro activity of exo- $\beta-1,3$-glucanase was measured as a possible biocontrol mode of action for C. oleophila. Mean disease incidence caused by P. expansum was $0.3 \%$ for apples treated with fludioxonil + ciprodinil, which were used as a positive control, and $1 \%$ for fruits treated with a combination of the three C. oleophila strains; the effects of these treatments were significantly equivalent. Disease incidence in control apples was $39 \%$ and was significantly different from the other treatments. The in vivo exo- $\beta$-1,3-glucanase activity began at $24 \mathrm{~h}$ and peaked at 72 and $96 \mathrm{~h}$ for all treatments. Strain L06 had the highest activity (7.96 nKat) and a specific activity of $2.92 \mathrm{nKat}^{-1} \mathrm{~g}^{-1}$. Candida albicans

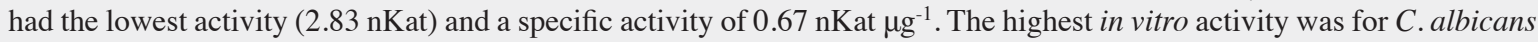
$(85.03 \mathrm{nKat})$ and the lowest for strain L06 (78.2 nKat). Significant differences in both in vivo and in vitro enzymatic activity were observed between strain L06 and C. albicans. Polynomial regression analysis $\left(\mathrm{R}^{2}=0.96\right.$ in vitro and 0.68 in vivo $)$ indicated that increased enzymatic activity was associated with reduced fruit disease incidence. The production of exo- $\beta$ 1,3-glucanase by $C$. oleophila is a possible mode of action for the efficient biocontrol of $P$. expansum on postharvest apples.

Key words: Biocontrol, Malus domestica, yeasts.

\section{INTRODUCTION}

Penicillium expansum Link, the causal agent of blue mold, is one of the most common fungi affecting postharvest apples (Jurick et al., 2011). This phytopathogenic fungus causes fruit losses ranging from $5 \%$ to $20 \%$ in developed countries (Cappellini and Ceponis, 1984) and up to $50 \%$ in developing countries (El-Ghaouth, 1997). Synthetic fungicides are still commonly used to control rots caused by blue mold on apples although most Penicillium species have developed resistance to most fungicides used to control them. An alternative to chemical control is using microorganisms that can control phytopathogenic fungi. The development of alternative methods, such as biological control with microorganisms, has increased in recent years (Wang et al., 2009). Blum

\footnotetext{
${ }^{1}$ Universidad Autónoma de Chihuahua, Facultad de Ciencias Agrotecnológicas, Campus Cuauhtémoc, Chih. Av. Presa de La Amistad 2015, Cuauhtémoc, Chihuahua C.P. 31510, México. *Corresponding author (vguerrero@uach.mx).

${ }^{2}$ Centro de Investigación en Recursos Naturales, DGETA-SEP, Salaices, Chihuahua, México.

${ }^{3}$ Centro de Investigación en Alimentación y Desarrollo, A.C., Unidad Cuauhtémoc, Av. Río Conchos s/n, Parque Industrial, Apdo. Postal 781, Cuauhtémoc, Chihuahua C.P. 31570, México.

Received: 30 January 2014.

Accepted: 4 April 2014.

doi: $10.4067 /$ S0718-58392014000400008
}

et al. (2004) used Cryptococcus laurentii isolated from apple fruit as a biological control agent in laboratory tests against $P$. expansum, Glomerella cingulata, and Pezicula malicorticis. They compared this yeast with synthetic fungicides, such as thiabendazole and iprodione, and found no differences among them and confirmed that $C$. laurentii is an efficient biological control agent.

Yeasts are a natural microbiotic component of the apple's surface. They are able to grow and reproduce rapidly on the surface of the fruit at low and high temperatures (4 and $37{ }^{\circ} \mathrm{C}$ ) and therefore have an advantage over other microorganisms used on postharvest apples (Guerrero-Prieto et al., 2004; 2011). Yeasts have been identified as potential antagonists for postharvest disease control because of characteristics that allow them to colonize the surfaces of either healthy or wounded fruits (Guerrero-Prieto et al., 2004; Droby et al., 2009; Sharma et al., 2009; Gholamnejad et al., 2010; GuerreroPrieto et al., 2011). Knowledge and understanding of yeast mode of action are prerequisites to develop successful biological control strategies. Various yeasts have acted as biocontrol agents of postharvest pathogens (Ippolito et al., 2000; Kurtzman and Droby, 2002) through various modes of action, including lytic enzyme production, induction of resistance, antibiosis, and nutrient and space competition (Droby et al., 2009; Sharma et al., 2009; GuerreroPrieto et al., 2011; Rivera-Avalos et al., 2012). Candida 
oleophila has been reported as a biocontrol agent for $P$. expansum and Botrytis cinerea on apples (Wisniewski et al., 1995; El-Neshawy and Wilson, 1997; Guerrero-Prieto et al., 2011). The cell wall of these fungi is composed primarily of $\beta$-glucans and other polymers, such as chitin and proteins, which together form a structural network that protects the cell (Schirmböck et al., 1994; Adams, 2004; Latgé, 2007). $\beta$-1,3-glucanases play an important role in partially degrading the cell wall of these fungi (Amey et al., 2003; King et al., 2011). Exo- $\beta-1,3-$ glucanases (glucan 1,3- $\beta$-D-glucosidases, E. C. 3.2.1.58) sequentially hydrolyze glycosidic bonds in the nonreducing end of 1,3- $\beta$-D-glucans and produce glucose as a final product. Endo- $\beta$-1,3-glucanases (glucan endo-1,3$\beta$-D-glucosidases, E.C. 3.2.1.39) randomly hydrolyze the inter-chain bonds and form small oligosaccharide chains as a final product (Vijayendra and Kashiwagi, 2009).

Several studies suggest that the production of lytic enzymes is a mode of action whereby yeasts degrade the cell wall and inhibit the growth of $P$. expansum (Oelofse et al., 2009). The objectives of the present study were to evaluate three strains of $C$. oleophila as biocontrol agents and determine their in vivo and in vitro activity of exo- $\beta$-1, 3-glucanase against $P$. expansum on postharvest apple (Malus domestica Borkh.) fruit.

\section{MATERIALS AND METHODS}

Experiments were performed at the Centro de Investigación en Alimentación y Desarrollo, A.C. (CIAD, A.C.) in Cuauhtemoc, Chihuahua, Mexico. The original $C$. oleophila strains (L06, L07 smooth, and L07 rough) were obtained from the epiphytic flora of 'Golden Delicious' apples and belong to the CIAD's strain collection "Microorganismos de la zona templada" (Temperate Zone Microorganism Collection) in Cuauhtemoc. The $P$. expansum strain was originally obtained from Oregon State University Mid-Columbia Agricultural Research Station, Hood River, Oregon, USA.

Physical and other characteristics of 'Golden Delicious' apples were as follows: fruit were harvested from a commercial orchard and cold stored ("La Nortenita" orchards and cold storage facility, Cuauhtemoc, Chihuahua. Mexico). Fruit, 21 per treatment, with no visible physical damage and an advanced degree of physiological maturity (postharvest apples) were randomly selected for the experiments. The fruit surface was disinfected with $1 \%$ sodium hypochlorite solution for 1 min before being used in the experiments.

Growth of microorganisms and inoculum preparation were as follows: $C$. oleophila strains were grown in NYDA medium (8 g nutrient broth, $5 \mathrm{~g}$ yeast extract, 10 $\mathrm{g}$ dextrose, and $15 \mathrm{~g}$ agar in $1 \mathrm{~L}$ distilled water) at $25^{\circ} \mathrm{C}$ for $48 \mathrm{~h}$. Strains were then inoculated in physiological saline solution and adjusted to a $1 \times 10^{7}\left(\mathrm{CFU} \mathrm{mL} \mathrm{mL}^{-1}\right)$ concentration. To obtain an enzymatic extract in vitro, yeasts were grown in NYDA, transferred to physiological saline solution, and the concentration adjusted to $1 \times 10^{7}$. The P. expansum Link strain was grown in PDA (potato dextrose agar) for $7 \mathrm{~d}$, transferred to physiological saline solution, and the concentration adjusted to $1 \times 10^{4}$ conidia $\mathrm{mL}^{-1}$. Concentrations were adjusted with a Neubauer chamber.

Evaluation of biocontrol efficiency was performed by punching two wells, each with a depth of $10 \mathrm{~mm}$ and a diameter of $3 \mathrm{~mm}$, into each apple that was inoculated with $30 \mu \mathrm{L}$ suspension of each of the $C$. oleophila strains or their combination at a concentration of $1 \times 10^{7} \mathrm{CFU}$ $\mathrm{mL}^{-1}$. Thirty minutes after the first inoculation, $30 \mu \mathrm{L}$ of $P$. expansum conidia suspension at a concentration of $1 \times 10^{9}$ CFU mL ${ }^{-1}$ was applied to the same well. The positive control consisted of apples in which the corresponding well was inoculated with only $P$. expansum. The negative control consisted of apples that were inoculated with only sterile water. A treatment with the chemical synthetic fungicide fludioxonil (4-(2,2-difluoro-1,3-benzodioxol-4-yl)-1Hpyrrole-3-carbonitrile) + cyprodinil (4-cyclopropyl-6methyl-N-phenylpyrimidin-2-amine) at a dose of 1 $\mathrm{g} \mathrm{L}^{-1}$ was also included. Apples were stored at $4{ }^{\circ} \mathrm{C}$. The diameter of the damaged area was evaluated on a weekly basis for 1 mo and used as an indicator of the damage caused by $P$. expansum. Disease incidence in the positive control was considered as $100 \%$ disease incidence, and disease incidence caused by the other treatments was calculated in relation to this value. Experiments were repeated three times and data were pooled into a single ANOVA.

\section{Obtaining enzymatic extract in vivo and in vitro}

Enzymatic extract for in vivo experiments was obtained from apples washed with $1 \%$ sodium hypochlorite solution for $1 \mathrm{~min}$. Wells with a diameter of $3 \mathrm{~mm}$ and depth of 5 mm were punched in each apple. Each well was inoculated with $35 \mu \mathrm{L}$ suspension of each $C$. oleophila isolate or their combination. Candida albicans was used as a positive control. Thirty minutes after yeast inoculation, the $P$. expansum conidia solution was inoculated in the same well of each apple. The negative control consisted of a treatment with only sterile distilled water. Each treatment was replicated three times. Inoculated fruits were placed in plastic bags to reach a high relative humidity (RH) and then stored at $24{ }^{\circ} \mathrm{C}$ for $7 \mathrm{~d}$. Tissue, $0.25 \mathrm{~g}$, was obtained from each well at $0,6,12,24,48,72$, and $96 \mathrm{~h}$ after inoculation. A $50 \mathrm{mM}$ solution of sodium acetate, 500 $\mu \mathrm{L},\left(\mathrm{pH} 5.0,4{ }^{\circ} \mathrm{C}\right)$ was added to each tissue sample and centrifuged for $15 \mathrm{~min}$ at $10,000 \mathrm{~g}$. Apple fruit tissue was then discarded and the supernatant precipitated by adding $70 \%$ acetone solution at $-20{ }^{\circ} \mathrm{C}$. The supernatant was centrifuged at $12.000 \mathrm{~g}$ for $30 \mathrm{~min}$, and the precipitate was washed twice with $70 \%$ acetone solution. The precipitate was suspended in $2 \mathrm{~mL}$ of $50 \mathrm{mM}$ sodium acetate buffer solution ( $\mathrm{pH}$ 5.0). This solution was used to determine 
exo- $\beta$-1,3-glucanase activity (Ippolito et al., 2000). Total protein was determined by Bradford's method (Bradford, 1976). Experiments were performed five times and data were then pooled and analyzed by ANOVA.

The enzymatic extract for the in vitro experiments was obtained from each one of the various isolates of C. oleophila and C. albicans that were grown in 250 mL NYDA (8 g nutrient broth, $5 \mathrm{~g}$ yeast extract, and $10 \mathrm{~g}$ dextrose in $1 \mathrm{~L}$ distilled water) at $25{ }^{\circ} \mathrm{C}$ for $3 \mathrm{~d}$. A raw extract, $5 \mathrm{~mL}$, was collected from each isolate and solubilized with $500 \mu \mathrm{L}$ of $50 \mathrm{mM}$ sodium acetate buffer at $4{ }^{\circ} \mathrm{C}$. This solution was centrifuged for $15 \mathrm{~min}$ at 10,000 $\mathrm{g}$, and the supernatant precipitated with $70 \%$ acetone at $-20{ }^{\circ} \mathrm{C}$. The solution was centrifuged at $12,000 \mathrm{~g}$ for 30 min and washed twice with $70 \%$ acetone. The precipitate was suspended in $2 \mathrm{~mL}$ of sodium acetate buffer solution; this suspension was used to measure exo- $\beta-1,3-$ glucanase enzymatic activity. When enzymatic activity was observed at the incubation times $(24,48,72$, and 96 h), 2-mL aliquots were drawn. Procedures to obtain the extract and determine exo- $\beta$-1,3-glucanase activity were performed as previously described for enzymatic extracts in vivo (Ippolito et al., 2000). Experiments were repeated five times, and data were then pooled to be analyzed by ANOVA.

\section{Determining exo- $\beta$-1,3-glucanase activity}

Exo- $\beta$-1,3-glucanase activity in the enzymatic extracts from in vitro and in vivo samples was measured by incubating them separately for $2 \mathrm{~h}$ at $40{ }^{\circ} \mathrm{C}$ with a $3 \%$ laminarin solution from Laminaria digitata as the substrate. Enzymatic reactions were run at $\mathrm{pH} 5.0$ and stopped by heating the sample for $10 \mathrm{~min}$ at $90{ }^{\circ} \mathrm{C}$. To each sample, $372 \mu \mathrm{L}$ of 3,5-dinitrosalicylic acid was added. The amount of glucose formed from laminarin was measured by spectrophotometry at $492 \mathrm{~nm}$. The final specific enzymatic activity was reported as nKat $\mu \mathrm{g}^{-1}$ of total protein; 1 nKat is defined as the enzymatic activity that catalyzes production of $1 \mathrm{nmol} \mathrm{s}{ }^{-1}$ glucose.

From the total in vivo exo- $\beta$-1,3-glucanase activity for each treatment, the natural activity of this enzyme on the apple fruit was determined and subtracted from total activity. The enzymatic activity was also measured in apple fruit pulp with no treatment. Exo- $\beta$-1,3-glucanase activity was measured for treatments with L06, L07 smooth, L07 rough, and their combination. The enzymatic activity of $C$. albicans was measured as a positive control.

\section{Statistical analysis}

Data were pooled and analyzed by ANOVA with the Statistix, version 9.0 software program (Analytical Software, Tallahassee, Florida, USA). Means were compared by Tukey's test $(\alpha=0.05)$. Relationships between fruit damage and exo- $\beta-1,3$-glucanase activity were evaluated by polynomial regression analysis.

\section{RESULTS}

\section{Control of $P$. expansum in vivo}

Apple fruit damage caused by P. expansum was greater when the pathogen was inoculated alone. The diameter of the damaged area on apples was reduced by adding each of the three $C$. oleophila isolates and by treating them with the chemical synthetic fungicide fludioxonil+cyprodinil. Apple fruit damage was reduced by the L06 and L07 rough strains and the combination of three C. oleophila strains; this damage was similar to synthetic fungicide used alone (Table 1).

\section{Exo- $\beta$-1,3-glucanase activity in vivo}

The three C. oleophila strains (L06, L07 smooth, L07 rough) and their combination showed exo- $\beta-1,3-$ glucanase activity when challenged by $P$. expansum on apples. Isolate L06 showed the highest enzymatic activity (7.96 nKat) and $C$. albicans the lowest (2.83 nKat) (Table $2)$. Exo- $\beta-1,3$-glucanase activity was first detected at 24 h. The highest enzymatic activity was detected at $72 \mathrm{~h}$ for L06 and L07 rough and at $96 \mathrm{~h}$ for L07 smooth, the combination of strains, and C.albicans (Figure 1).

\section{Exo-p-1,3-glucanase activity in vitro}

The $C$. oleophila isolates displayed exo- $\beta-1,3$-glucanase activity when grown in NYDA. Candida albicans had the highest enzymatic activity (85.03 nKat) and strain L06 the

Table 1.In vivo Penicillium expansum disease incidence on postharvest 'Golden Delicious' apples when challenged by three Candida oleophila strains their combination, and fludioxonil+cyprodinil.

\begin{tabular}{lcc}
\hline Treatments & Disease incidence & Disease reduction \\
\cline { 2 - 3 } P. expansum & $39 \mathrm{a}$ & - \\
L07 smooth & $11 \mathrm{~b}$ & 72 \\
L06 & $7 \mathrm{bc}$ & 82 \\
L07 rough & $7 \mathrm{bc}$ & 82 \\
Strain combination & $1 \mathrm{bc}$ & 97 \\
Fludioxonil + cyprodinil & $0.3 \mathrm{c}$ & 99 \\
Negative control & $0.3 \mathrm{c}$ & 99 \\
\hline
\end{tabular}

Means with different letters are significantly different according to Tukey's test $(\mathrm{P}<0.05)$

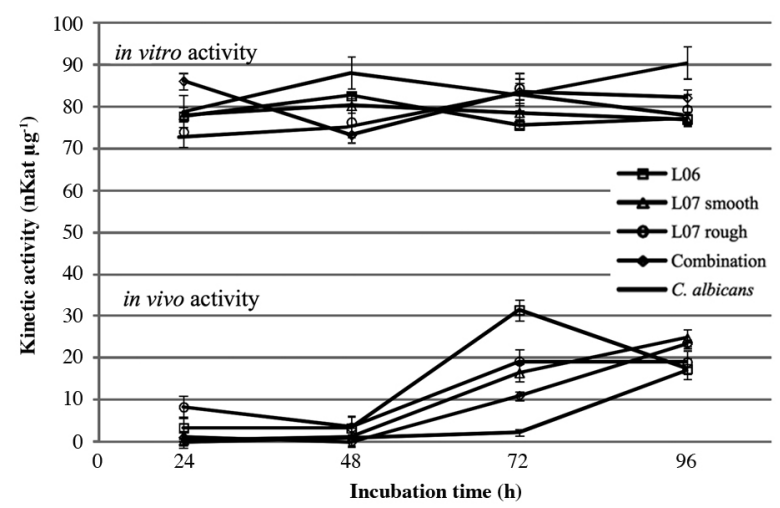

Figure 1. In vitro and in vivo kinetic activity of exo-B-1,3-glucanase for three Candida oleophila strains. 
lowest (78.23 nKat) (Table 2). The enzymatic activity for these two strains measured in vitro differed from the in vivo measurements. The highest enzymatic activity was observed at 24 and $72 \mathrm{~h}$ for C. albicans, at 24 and $48 \mathrm{~h}$ for the combination of the three $C$. oleophila isolates, and at $72 \mathrm{~h}$ for the L07 rough isolate (Figure 1).

A relationship was observed between exo- $\beta-1,3-$ glucanase enzymatic activity (both in vivo and in vitro) and apple fruit damage. A polynomial relationship was obtained, that is, enzymatic activity increased as apple fruit damage decreased. Data fitness was higher for in vitro enzymatic activity $\left(\mathrm{R}^{2}=0.99\right)$ than in vivo activity $\left(\mathrm{R}^{2}=0.68\right)$ (Figure 2).
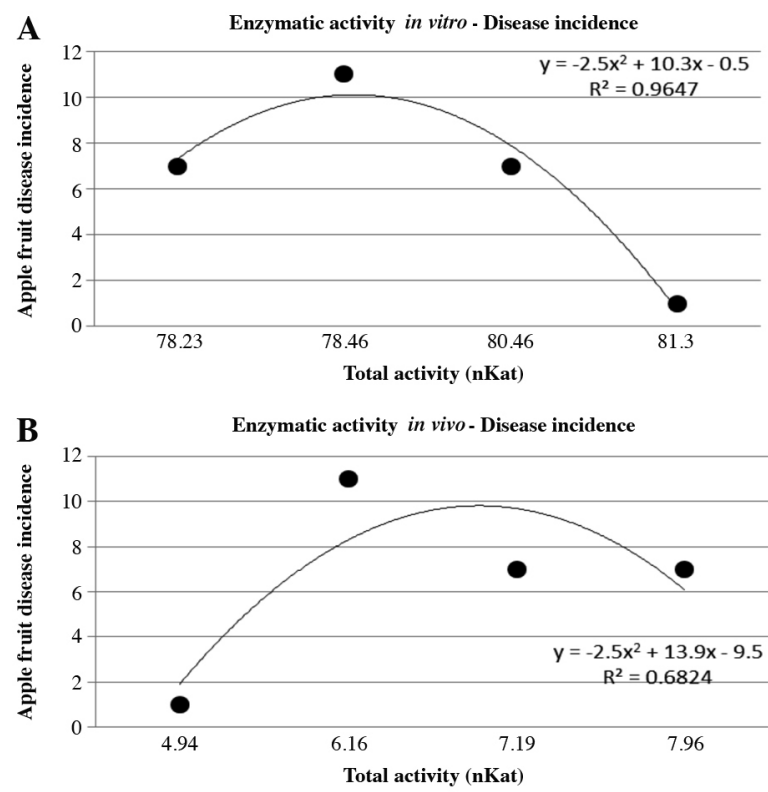

Figure 2. Polynomial relationship between enzymatic activity and apple fruit disease incidence caused by Penicillium expansum in vitro (A) and in vivo (B).

Table 2. Total protein and exo- $\beta-1,3$-glucanase activity for three Candida oleophila strains when challenged by Penicillium expansum on postharvest 'Golden Delicious' apples.

\begin{tabular}{lccccc}
\hline & \multicolumn{2}{c}{ in vivo } & & \multicolumn{2}{c}{ in vitro } \\
\cline { 2 - 3 } \cline { 5 - 6 } Strains & $\begin{array}{c}\text { Total } \\
\text { protein }\end{array}$ & $\begin{array}{c}\text { Total } \\
\text { activity }\end{array}$ & & $\begin{array}{c}\text { Specific } \\
\text { activity }\end{array}$ & $\begin{array}{c}\text { Total } \\
\text { activity }\end{array}$ \\
\hline & $\mu \mathrm{g} \mathrm{mL}^{-1}$ & $\mathrm{nKat}$ & & ${\mathrm{nKat} \mu \mathrm{g}^{-1}}^{\mathrm{n}}$ & $\mathrm{nKat}$ \\
L06 & $2.73 \mathrm{c}$ & $7.96 \mathrm{a}$ & & 2.92 & $78.23 \mathrm{~b}$ \\
L07 rough & $2.73 \mathrm{c}$ & $7.19 \mathrm{ab}$ & & 2.63 & $80.46 \mathrm{ab}$ \\
L07 smooth & $2.43 \mathrm{~d}$ & $6.16 \mathrm{ab}$ & & 2.53 & $78.46 \mathrm{~b}$ \\
Strain combination & $3.10 \mathrm{~b}$ & $4.94 \mathrm{bc}$ & & 1.59 & $81.30 \mathrm{ab}$ \\
C. albicans & $4.21 \mathrm{a}$ & $2.83 \mathrm{c}$ & & 0.67 & $85.03 \mathrm{a}$ \\
\hline
\end{tabular}

Means followed by different letters within a column are significantly different according to Tukey's test $(\mathrm{P}<0.05)$.

\section{DISCUSSION}

Damage caused by P. expansum on apples was efficiently controlled by strains L06 and L07 rough, either combined or separately, and by the synthetic fungicide used alone. Thus, the effects of the evaluated $C$. oleophila strains in controlling postharvest apple fruit damage caused by $P$. expansum were indistinguishable from those of the evaluated synthetic fungicide. These results indicate that the evaluated $C$. oleophila strains are a viable alternative for P. expansum biocontrol. Candida oleophila has been reported as an exo- $\beta$-1,3-glucanase producer (Bar-Shimon et al., 2004). This enzyme is capable of degrading the cell wall and decreasing spore germination and mycelium growth of phytopathogenic fungi (Lin et al., 2007). Our results clearly demonstrate exo- $\beta$-1,3-glucanase activity in $C$. oleophila strains evaluated in both in vivo and in vitro. We observed numerical differences in enzymatic activity between both growth conditions; in vitro activity was slightly more than ten times higher than in vivo activity. In vitro activity of L06 and L07 rough strains, either alone or combined, was the same. In vitro activity for $C$. albicans was the highest, while the lowest was in the L06 strain. Bar-Shimon et al. (2004) reported that in vitro exo- $\beta$-1,3-glucanase activity of $C$. oleophila was higher during the first developmental stages. In contrast, we observed a variable enzymatic activity during the evaluated period of time. Enzymatic activity of the L06 strain was higher in vivo; it was higher for this strain used alone than when it was combined with the other two strains. The observed differences for in vitro and in vivo enzymatic activity in the evaluated $C$. oleophila strains suggest that they have a higher exo- $\beta-1,3$-glucanase activity when directly challenged by $P$. expansum. Observed responses for the evaluated $C$. oleophila strains (particularly strain L06) suggest that they could be very useful in the biological control of P. expansum. Strain L06 displayed the highest enzymatic activity in vivo and when challenged by the fungus. A similar response for C. oleophila was reported by Bar-Shimon et al. (2004), who observed higher enzymatic activity for yeast grown in culture media enriched with $P$. digitatum cell wall fragments plus glucose. $\beta$-1,3-glucanase activity by other yeasts on fruit was reported by Fan et al. (2002).

The results of the present study clearly indicate that the three evaluated $C$. oleophila strains produce lytic enzymes with exo- $\beta$-1,3-glucanase activity. Enzymatic activity in both in vivo and in vitro was best fitted to a polynomial relationship in which increased enzymatic activity resulted in reduced apple fruit damage. Exo- $\beta$ 1,3-glucanase produced by the evaluated $C$. oleophila strains could play an important role as a mode of action for the biocontrol of P. expansum. The L06 and L07 rough isolates have a high potential for development as biocontrol agents against $P$. expansum on postharvest apples and may provide a viable alternative for biocontrol under postharvest conditions.

\section{CONCLUSIONS}

Penicillium expansum disease reduction on postharvest apple fruit was complete when using the combination of 
the three Candida oleophila yeasts as well as when using synthetic fungicide. One of the possible modes of action used by yeasts was the production of exo- $\beta$-1,3-glucanase.

\section{ACKNOWLEDGEMENTS}

The authors acknowledge Fondo Mixto Estado de Chihuahua - CONACYT, Mexico, for grant project CHIH.-2006-CO2-58803. The authors also thank "La Norteñita", Cuauhtemoc, Chihuahua, Mexico for providing the apples.

\section{LITERATURE CITED}

Adams, D.J. 2004. Fungal cell wall chitinases and glucanases. Microbiology 150:2029-2035.

Amey, R.C., P.R. Mills, A. Bailey, and G.D. Foster. 2003. Investigating the role of a Verticillium fungicola $\beta$-1,6-glucanase during infection of Agaricus bisporus using targeted gene disruption. Fungal Genetics and Biology 39:264-275.

Bar-Shimon, M., H. Yehuda, L. Cohen, B. Weiss, A. Kobeshnikov, A. Daus, et al. 2004. Characterization of extracellular lytic enzymes produced by the yeast biocontrol agent Candida oleophila. Current Genetics 45:140-148.

Blum, L., C. Amarante, R. Valdebenito-Sanhueza, L. Guimarães, A. Dezanet, e P. Hack-Neto. 2004. Cryptococcus laurentii aplicado em pós-colheita reduz podridões em maçãs. Fitopatologia Brasileira 29:433-436.

Bradford, M. 1976. A rapid and sensitive method for the quantitation microgram quantities of protein utilizing the principle of proteindye binding. Annals of Biochemistry 72:248-254.

Cappellini, R., and M. Ceponis. 1984. Postharvest losses in fresh fruits and vegetables. Plant Pathology 132:24-30.

Droby, S., M. Wisniewski, D. Macarisin, and C. Wilson. 2009. Twenty years of postharvest biocontrol research: Is it time for a new paradigm? Postharvest Biology and Technology 52:137-145.

El-Ghaouth, A. 1997. Biologically-based alternatives to synthetic fungicides for the control of postharvest diseases. Journal of Industrial Microbiology and Biotechnology 19:160-162.

El-Neshawy, S.M., and C.L. Wilson. 1997. Nisin enhancement of biocontrol of postharvest diseases of apple with Candida oleophila. Postharvest Biology and Technology 10:9-14.

Fan, Q., S. Tian, H. Liu, and Y. Xu. 2002. Production of $\beta-1,3-$ glucanase and chitinase of two biocontrol agents and their possible modes of action. Chinese Science Bulletin 47:292-296.

Gholamnejad, J., H.R. Etebarian, and N. Sahebani. 2010. Biological control of apple blue mold with Candida membranifaciens and Rhodotorula mucilaginosa. African Journal of Food Science 4:1-7.

Guerrero-Prieto, V.M., A.C. Blanco-Perez, C. Guigon-Lopez, C.J. Tamayo-Urbina, F.J. Molina-Corral, D.I. Berlanga-Reyes, et al. 2011. Competencia por nutrientes; modo de acción de Candida oleophila Montrocher contra Penicillium expansum Link y Botrytis cinerea (Pers.) Revista Mexicana de Fitopatología 29:90-97.
Guerrero-Prieto, V., G. Trevizo, C. Figueroa, A. Romo, A. Gardea, C. Blanco, et al. 2004. Identificación de levaduras epifitas obtenidas de manzana [Malus sylvestris (L.) Mill. var. domestica (Borkh.) Mansf.] para control biológico poscosecha. Revista Mexicana de Fitopatología 22:223-230.

Ippolito, A., A. El-Ghaouth, C. Wilson, and M. Wisniewski. 2000. Control of postharvest decay of apple fruit by Aureobasidium pullulans and induction of defense responses. Postharvest Biology and Technology 19:265-272.

Jurick, W.M.II, W.J. Janisiewicz, R.A. Saftner, I. Vico, V.L. Gaskins, E. Park, et al. 2011. Identification of wild apple germplasm (Malus spp.) accessions with resistance to the postharvest decay pathogens Penicillium expansum and Colletotrichum acutatum. Plant Breeding 130:481-486.

King, B.C., K.D. Waxman, N.V. Nenni, L.P. Walker, G.C. Bergstrom, and D.M. Gibson. 2011. Arsenal of plant cell wall degrading enzymes reflects host preference among plant pathogenic fungi. Biotechnology for Biofuels 4:4.

Kurtzman, C., and S. Droby. 2002. Metschnikowia fructicola, a new ascosporic yeast with potential for biocontrol of postharvest fruit rots. Systematic and Applied Microbiology 24:395-399.

Latgé, J.P. 2007. The cell wall: a carbohydrate armour for the fungal cell. Molecular Microbiology 66:279-290.

Lin, C., J. Yang, and H. Sun. 2007. Purification and characterization of a $\beta$-1,3-glucanase from the novel mycoparasite Periconia byssoides. Biotechnology Letters 29:617-622.

Oelofse, D., I. Dubery, and D.K. Berger. 2009. Exo-ß-1,3-glucanase from yeast inhibits Colletotrichum lupini and Botrytis cinerea spore germination. Journal of Phytopathology 157:1-6.

Rivera-Avalos, S., R.A. Martínez-Peniche, L. Soto-Muñoz, y M.S. Chávaro-Ortiz. 2012. Modos de acción de cuatro cepas de levaduras antagónicas contra Penicillium expansum Link en manzana. Revista Chapingo Serie Horticultura 18:227-238.

Schirmböck, M., M. Lorito, Y.I. Wang, C.K. Hayes, I. Arisan-Atac, F. Scala, et al. 1994. Parallel formation and synergism of hydrolytic enzymes and peptaibol antibiotics, molecular mechanisms involved in the antagonistic action of Trichoderma harzianum against phytopathogenic fungi. Applied and Environmental Microbiology 60:4364-4370,

Sharma, R.R., D. Singh, and R. Singh. 2009. Biological control of postharvest diseases of fruits and vegetables by microbial antagonists: A review. Biological Control 50:205-221.

Vijayendra, S.V.N., and Y. Kashiwagi. 2009. Characterization of a new acid stable exo-3-1,3-glucanase of Rhizoctonia solani and its action on microbial polysaccharides. International Journal of Biological Macromolecules 44:92-97.

Wang, Y., T. Yu, Y. Li, D. Cai, X. Liu, H. Lu, et al. 2009. Postharvest biocontrol of Alternaria alternata in Chinese winter jujube by Rhodosporidium paludigenum. Journal of Applied Microbiology 107:1492-1498.

Wisniewski, M., S. Droby, E. Chalutz, and Y. Eilam. 1995. Effects of $\mathrm{Ca}^{2+}$ and $\mathrm{Mg}^{2+}$ on Botrytis cinerea and Penicillium expansum in vitro and on the biocontrol activity of Candida oleophila. Plant Pathology 44:1016-1024. 